\title{
Tinjauan Deskriptif Penerapan Higher Order Thinking dan Problem-Based Learning Pada Mata Kuliah Geometri Berdasarkan Kemampuan Matematika Mahasiswa
}

\author{
Andri Anugrahana \\ andrianugrahana@gmail.com \\ PGSD Universitas Sanata Dharma

\section{Descriptive Evaluation of Higher Order Thinking Implementation in Geometry Course on Student's Mathematic Ability}

\begin{abstract}
Teaching and learning process in the classroom tends to use the process of memorizing and using the concept in Bloom's taxonomy. This study developed questions that invites students to perform high-level skill process of analyzing, evaluating, and creating, according to Bloom's taxonomy, which are the indicators of HOT (Higher Order Thinking). The HOT process is derived from students experience in learning and the knowledge of each student. This qualitative descriptive research aims to obtain a description of the HOT problem-solving process in the geometry course. Subjects in this study were 50 prospective elementary school teachers. The learning process begins with the students getting the problems given by the teacher, then discussing it in groups, and providing opportunities for students to express opinions or thoughts orally. The data collection was the results of the student's thinking process, problem-solving skills test, and interviews. The data analysis was done by doing data reduction, data presentation, also drawing conclusion and verification. The result showed that students experiencing high level skill process of analyzing, evaluating and creating. In the process of analyzing, the students proved the formula of the area of twodimensional figures. In evaluating the stages, the students in the group conducted the examination, made guesses, did the experiment, and tested the allegations of what has been done. Furthermore, students were able to create and find various answers in the form of twodimensional figures.
\end{abstract}

Keywords: higher order thinking, mathematics, elementary school, problem-solving

Received date: 20 Februari 2018

Article Info

Revised date: 2 Mei $2018 \quad$ Accepted date: 4 Mei 2018

\section{PENDAHULUAN}

Perkembangan pengetahuan dan teknologi infomasi semakin pesat, sehingga banyak pengetahuan yang dapat diperoleh dengan cepat. Mahasiswa diharapkan mampu bersaing dalam era yang semakin maju karena perkembangan teknologi. Matematika merupakan dasar yang membekali siswa untuk dapat bertahan dalam kondisi yang terus berubah. Dasar yang perlu dibekalkan kepada mahasiswa adalah mengembangkan kemampuan berpikir kritis, sistematis, logis, kreatif, dan kemampuan bekerjasama dalam mengolah informasi. Keterampilan berpikir seperti ini dapat dikembangkan melalui belajar matematika, karena matematika memiliki struktur dan keterkaitan yang kuat dan jelas antar konsepnya sehingga memungkinkan siswa terampil berpikir rasional (Depdiknas, 2003).

Salah satu konsep yang dibekali pada mahasiswa adalah konsep geometri. Tujuan dari pembelajaran matematika khususnya mata kuliah geometri adalah untuk memberi pengalaman belajar tentang berbagai konsep geometri yang relevan untuk tingkat sekolah dasar melalui berbagai metode pembelajaran. Kajian konsep 'Geometri dan Pengukuran' meliputi konsep keruangan yang bersifat kontekstual, sehingga diharapkan mahasiswa dapat mengkaitkan konsep dengan permasalahan dalam kehidupan sehari-hari. Pembelajaran yang 
terjadi di dalam kelas cenderung mengunakan pembelajaran yang mendominasi pada proses kemampuan menghafal dan menggunakan konsep. Untuk itu, dalam penelitian ini mengajak mahasiswa untuk melakukan proses ketrampilan tingkat tinggi yaitu menganalisis, mengevaluasi dan mengkreasi dengan menggunakan model pembelajaran Problem-based Learning.

Proses menganalisis, mengevaluasi, dan mengkreasi merupakan indikator dalam HOT (Higher Order Thinking). Proses HOT diperoleh dari pengalaman mahasiswa dalam pembelajaran dan pengetahuan masing-masing mahasiswa. Mahasiswa diajak untuk mengkontruksi untuk membangun suatu pengetahuan dalam dirinya sehingga mampu memiliki kesadaran dalam pembelajaran. Proses belajar seperti ini dapat membuat mahasiswa berkembang dan memiliki kemampuan bernalar. Hal ini menunjukkan bahwa proses pembelajaran matematika sudah tidak terfokus pada kemampuan menghapal saja tetapi lebih pada kemampuan menggunakan konsep dan kemampuan mengembangkan keterampilan tingkat tinggi. Tujuan dalam penelitian ini adalah untuk mengetahui proses analisis mahasiswa dalam menggunakan proses HOT dalam menyelesaikan permasalahan ataupun soal dalam pembelajaran Geometri.

\section{KAJIAN PUSTAKA}

Fokus utama tujuan pembelajaran matematika adalah mengembangkan higher order thinking skills (HOTS) mahasiswa. Fokus utama tujuan pembelajaran matematika dan tuntutan kurikulum adalah mengembangkan higher order thinking skills (HOTS) siswa. HOTS merupakan kemampuan berpikir yang terdiri atas berpikir kritis, berpikir kreatif, dan pemecahan masalah (Brookhart, 2010; Retnawati, 2016). Model pembelajaran Problembased Learning merupakan salah satu model pembelajaran yang dapat mengadopsi soal-soal HOTS.

Higher order thinking skills (HOTS) adalah kemampuan memberi alasan secara terorganisasi dan mengevaluasi kualitas suatu alasan secara sistematis (Ade Gunawan, 2012). Yanti Rahmawati (2013) Berpir kritis itu sendiri merupakan proses menganalisis atau mengevaluasi informasi suatu masalah berdasarkan pemikiran yang logis untuk menentukan keputusan. Beberapa pendapa tersebut maka dapat disimpulkan bahawa berpikir kritis adalah proses menganalisis, mengevaluasi pengetahuan yang diterima siswa selama proses pembelajaran.

Krathwohl (2012) menuliskan

"Analyze, breaking material into its constituent part and detecting how the parts relate to one another and to an overall structure or purpose (differentiating, organizing, attributing). Evaluate, making judgments based on criteria and standards (checking, critiquing). Create, putting elements together to form a novel, coherent whole or make an original product (generating, planning, producing)".

Dengan melakukan analsis berarti melakukan pemecahan masalah dan mencari hubungan satu sama lain. Yang merupakan bagian dalam analisis adalah membedakan, mengatur, dan membuat atribut. Evaluasi artinya membuat penilaian berdasarkan kriteria dan standar. Bagian dalam evaluasi adalah memeriksa dan mengkritik, sedangkan mengkreasi artinya membuat generalisasi. Bagian dalam mengkreasi adalah menghasilkan, merencanakan, dan memroduksi. Hal senada disampaikan oleh Aisyah (2009) yang mengutip pendapat Krathwohl bahwa indikator untuk mengukur kemampuan berpikir tingkat tinggi (HOT) adalah (1) menganalisis, meliputi menganalisis informasi yang masuk dan membagibagi atau menstrukturkan informasi ke dalam bagian yang lebih kecil untuk mengenali pola atau hubungannya, mampu mengenali serta membedakan faktor penyebab dan akibat dari sebuah skenario yang rumit, mengidentifikasi/merumuskan pertanyaan; (2) mengevaluasi, 
meliputi: memberikan penilaian terhadap solusi, gagasan, dan metodologi dengan menggunakan kriteria yang cocok atau standar yang ada untuk memastikan nilai efektivitas atau manfaatnya, membuat hipotesis, mengkritik dan melakukan pengujian, menerima atau menolak suatu pernyataan berdasarkan kriteria yang telah ditetapkan; (3) mengkreasi meliputi: membuat generalisasi suatu ide atau cara pandang terhadap sesuatu, merancang suatu cara untuk menyelesaikan masalah, mengorganisasikan unsur-unsur atau bagian-bagian menjadi struktur baru yang belum pernah ada sebelumnya.

Ranah dalam Taksonomi Bloom digunakan untuk mengukur kemampuan berpikir tingkat tinggi seperti yang diungkap oleh Krathwohl (dalam Aisyah 2009). Indikator untuk mengukur kemampuan berpikir tinggi meliputi menganalisis, mengevaluasi dan mengkreasi:

1. Analyze (menganalisis), yaitu memisahkan materi menjadi bagian-bagian penyusunannya dan mendeteksi bagaimana suatu bagian berhubungan dengan satu bagiannya yang lain.

a. Differentiating (membedakan) terjadi ketika siswa membedakan bagian yang tidak relevan dan yang relevan atau dari bagian yang penting ke bagian yang tidak penting dari suatu materi yang diberikan.

b. Organizing (mengorganisasikan) menentukan bagaimana suatu bagian elemen tersebut cocok dan dapat berfungsi bersama-sama didalam suatu struktur.

c. Attributing (menghubungkan) terjadi ketika siswa dapat menentukan inti atau menggaris bawahi suatu materi yang diberikan.

2. Evaluate (mengevaluasi) yaitu membuat keputusan berdasarkan kreteria yang standar, seperti mengecek dan mengkritik.

a. Checking (mengecek) terjadi ketika siswa melacak ketidak konsistenan suatu proses atau hasil, menentukan proses atau hasil yang memiliki kekonsistenan internal atau mendeteksi keefektifan suatu prosedur yang sedang diterapkan.

b. Critiquing (mengkritisi) terjadi ketika siswa mendeteksi ketidak konsistenan antara hasil dan beberapa kriteria luar atau keputusan yang sesuai dengan prosedur masalah yang diberikan.

3. Create (menciptakan) yaitu menempatkan element bersama-sama untuk membentuk suatu keseluruhan yang koheren atau membuat hasil yang asli, seperti menyusun, merencanakan dan menghasilkan.

a. Generating (menyusun) melibatkan penemuan hipotesis berdasarkan kreteria yang diberikan.

b. Planning (merencanakan) suatu cara untuk membuat rancangan untuk menyelesaikan suatu tugas yang diberikan.

c. Producing (menghasilkan) membuat sebuah produk. Pada producing, siswa diberikan deskripsi dari suatu hasil dan harus menciptakan produk yang sesuai dengan diskripsi yang diberikan

Menurut Alexander (Brookhart, 2010) "Higher-order thinking is the mental engagement with ideas, objects, and situations, ...”. Berpikir tingkat tinggi adalah keterlibatan mental dengan ide, objek, dan situasi. Hal ini menunjukkan bahwa HOT memiliki aspek yang sangat penting untuk dikembangkan khususnya dalam pembelajaran matematika. Tujuan pembelajaran yang mengembangkan HOT adalah untuk membekali mahasiswa terampil memberi alasan dan membuat keputusan (Brookharth, 2010). HOT dalam pembelajaran matematika dapat ditunjukkan dengan mahasiswa mampu menyelesaikan permasalahan-permasalahan matematika dan mampu memberikan alasan dari permasalahan yang diberikan. Oleh karena itu, saat menggunakan HOT, mahasiswa perlu memutuskan apa yang harus dilakukan, menciptakan ide-ide baru, membuat prediksi dan memecahkan masalah non-rutin. (Retnawati, 2016) 
Mengembangkan HOTS memerlukan ketrampilan pendidik dalam merencanakan dan mengelola pembelajaran yang efektif untuk menuntun mahasiswa melakukan proses HOTS sehingga mahasiswa mampu menyelesaikan permasalahan geometri dengan kritis dan kreatif. Hal ini juga didukung dari hasil penelitian yang dilakukan oleh Murray (2011) bahwa pentingnya HOTS dalam pembelajaran juga ditunjukkan ketika siswa menggunakan HOTS maka siswa memutuskan apa yang harus dipercayai dan apa yang harus dilakukan, menciptakan ide-ide baru, membuat prediksi dan memecahkan masalah non-rutin.

As'ari (Fadjar, 2007) mengatakan karakteristik pembelajaran matematika saat ini adalah lebih fokus pada kemampuan prosedural, komunikasi satu arah, pengaturan kelas monoton, low order thinking skill, bergantung pada buku paket, lebih dominan soal rutin dan pertanyaan tingkat rendah. Karenanya perlu adanya perubahan proses belajar di kelas yang meningkatkan pemikiran tingkat tinggi. Pembelajaran yang baik adalah pembelajaran yang membiasakan pembelajaran berbasis pada pengembangan kemampuan berpikir yang lebih HOTS. Mahasiswa mulai dibiasakan dengan permasalahan-permasalahan atau soal-soal yang lebih membantu mahasiswa berpikir HOTS dan open ended.

Model soal yang disajikan dalam HOTS adalah yang melibatkan proses berpikir tingkat tinggi cenderung kompleks dan merupakan soal yang memiliki banyak solusi sehingga dapat dikatakan bahwa jenis soal HOT salah satunya merupakan soal open-ended. Sesuai dengan pendapat Resnick (dalam Arends, 2008) higher order thinking tends to be complex and often yields multiple solution. Ketika siswa dihadapkan oleh soal open-ended akan menghasilkan berbagai macam jawaban sesuai dengan pengalaman dan pengetahuan masing-masing individu. Hal ini tidak terlepas dari kemampuan tinggi, sedang, dan rendah mahasiswa. Disinilah peran fasilitator dalam hal ini adalah dosen, dengan memberikan permasalah berupa soal yang lebih bersifat open-ended.

Nishitani (2010) menuliskan "High level mathematical tasks are nonroutine processes. Therefore, to solve the tasks, students should have strong motivation, enthusiasm, and willingness to solve them". Hal ini berarti bahwa tugas ataupun soal dalam matematika merupakan salah satu soal non-routine (soal yang tidak diketahui secara langsung penyelesaiannya) oleh karenanya mahasiswa harus memiliki motivasi yang kuat, antusiasme dalam mengerjakan soal, dan kemauan untuk menyelesaikannya.

\section{METODE PENELITIAN}

Subjek dalam penelitian ini adalah seluruh mahasiswa yang terlibat dalam mata kuliah pendidikan matematika yang terdiri dari 50 mahasiswa dengan menggunakan model pembelajaran Problem-based Learning. Data penelitian ini adalah tanggapan dan juga proses berpikir mahasiswa terhadap pembelajaran geometri di kelas. Penelitian ini merupakan penelitian deskriptif kualitatif yang bertujuan untuk memperoleh deskripsi proses penyelesaian soal HOT pada mata kuliah geometri. Subjek dalam penelitian ini adalah 50 mahasiswa calon guru SD. Tujuan penelitian ini adalah untuk mengetahui kemampuan $H O T$ dan hasil belajar mahasiswa. Untuk itu perlu dilakukan penelitian tindakan kelas meliputi tahapan perencanaan, pelaksanaan, pengamatan, dan refleksi.

Data primer yang digunakan adalah kuesioner yang dibagikan di awal dan di akhir perkuliahan. Sedangkan data sekunder adalah hasil refleksi dari mahasiswa. Instrumen yang digunakan untuk menggali data dalam penelitian ini adalah kuisioner, simulasi penerapan model Problem-based Learning dan hasil refleksi mengajar. 


\section{HASIL DAN PEMBAHASAN}

Materi yang diajarkan adalah luas permukaan dari bangun datar. Pelaksanaan kegiatan pembelajaran didasarkan pada silabus yang sudah dirancang bersama tim pengajar yang lainnya. Langkah selanjutnya mahasiswa diajak untuk melihat konsep geometri. Kegiatan perkuliahan dilakukan dengan memberikan permasalahan yang berkaitan dengan bangun datar. Dengan menggunakan bahan dan alat yang sudah disiapkan mahasiswa membuktikan luas dari bangun datar. Mahasiswa mencari kemungkinan jawaban dari setiap bangun datar yang disajikan. Pemanfaatan media dalam pembelajaran dapat membantu mahasiswa dalam mengkontruksi pengetahuannya. Pemanfaatan media ini sejalan dengan Rapina Nugrahani (2007, 36) yang menyatakan bahwa media merupakan alat bantu yang berguna dalam kegiatan pembelajaran untuk mentransfer pengetahuan. Berikut adalah beberapa hasil analisa yang dilakukan oleh mahasiswa. Hasil analisa berdasar proses keterampilan tingkat tinggi yaitu menganalisis, mengevaluasi dan mengkreasi.

Proses menganalisa membuktikan rumus dari luas bidang datar. Untuk keperluan pembuktian mahasiswa dapat menggunakan kertas dan mencari luas dari bangun datar persegi, persegi panjang, segitiga, jajar genjang, belah ketupat, layang-layang, trapesium, lingkaran. Pada tahap mengevaluasi, mahasiswa dalam kelompok melakukan pemeriksaan, melakukan dugaan, percobaan dan menguji dugaan-dugaan dari yang sudah dilakukan. Selanjutnya mengkreasi, agar mahasiswa mampu menciptakan dan menemukan berbagaai kemungkinan jawaban dalam pembuktian bangun datar. Berikut adalah hasil mengkreasi mahasiswa.

\begin{tabular}{|c|c|c|c|}
\hline Bangun datar & \multicolumn{3}{|c|}{ Proses berpikir yang dilakukan mahasiswa } \\
\hline \multirow[t]{7}{*}{ 1. Persegi } & \multicolumn{3}{|c|}{$\begin{array}{l}\text { Pembuktian luas bangun datar saya mendapatkan banyak pelajaran diantaranya: untuk } \\
\text { membuktikan luas persegi dapat dengan memotong kertas menjadi persegi yang } \\
\text { lumayan besar kemudian dilipat menjadi beberapa bagian. Bagian-bagian kecil dari } \\
\text { persegi tersebut disebut persegi satuan. Selanjutnya persegi panjang diperoleh dari } \\
\text { dua persegi yang disatukan sehingga alas dua persegi menjadi panjang persegi dan sisi } \\
\text { samping menjadi lebar persegi panjang. }\end{array}$} \\
\hline & \multicolumn{3}{|c|}{$\begin{array}{l}\text { Sehingga kami mendapatkan hasil dengan cara memotong bangun datar lebih kecil } \\
\text { lagi. Seperti contoh pada persegi. Kami memotong-motong persegi menjadi } 16 \text { kotak } \\
\text { kecil atau bisa disebut } 16 \text { satuan kecil (persegi satuan). Sehingga kami bisa } \\
\text { mendapatkan rumus luas }=\text { sisi x sisi dengan uji coba luas }=4 \text { x } 4=16 \text {. Terbukti } \\
\text { bahwa } 4 \text { sisi bawah atau atas yang dikalikan } 4 \text { kotak yang ada di sisi kiri atau kanan } \\
\text { menghasilkan } 16 \text { kotak kecil (persegi satuan). }\end{array}$} \\
\hline & \multirow{3}{*}{$s$} & 2 & 3 \\
\hline & & $\bar{r}$ & 6 \\
\hline & & & 9 \\
\hline & \multicolumn{3}{|c|}{ 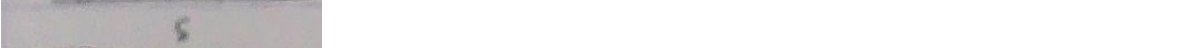 } \\
\hline & \multicolumn{3}{|c|}{ Untuk mencari luas persegi dapat di lakukan dengan cara menghitung persegi satuan } \\
\hline Keterangan & \multicolumn{3}{|c|}{$\begin{array}{l}\text { Hal ini menunjukkan tahap mengkreasi dimana mahasiswa mampu membuktikan dan } \\
\text { menemukan rumus dari luas persegi. Perolehan rumus persegi dengan cara } \\
\text { menghiung banyaknya persegi satuan. }\end{array}$} \\
\hline $\begin{array}{l}\text { 2. Persegi } \\
\text { Panjang }\end{array}$ & \multicolumn{3}{|c|}{$\begin{array}{l}\text { Untuk mendapatkan informasi kami mencari dari internet serta bertanya dengan } \\
\text { teman yang lebih paham, kami mulai ada gambaran tentang hal tersebut bahwa } \\
\text { ternyata bangun datar satu dengan yang lainnya saling berhubungan. Kami } \\
\text { melanjutkan ternyata didapatkan dari setengah rumus persegi dan persegi panjang }\end{array}$} \\
\hline
\end{tabular}




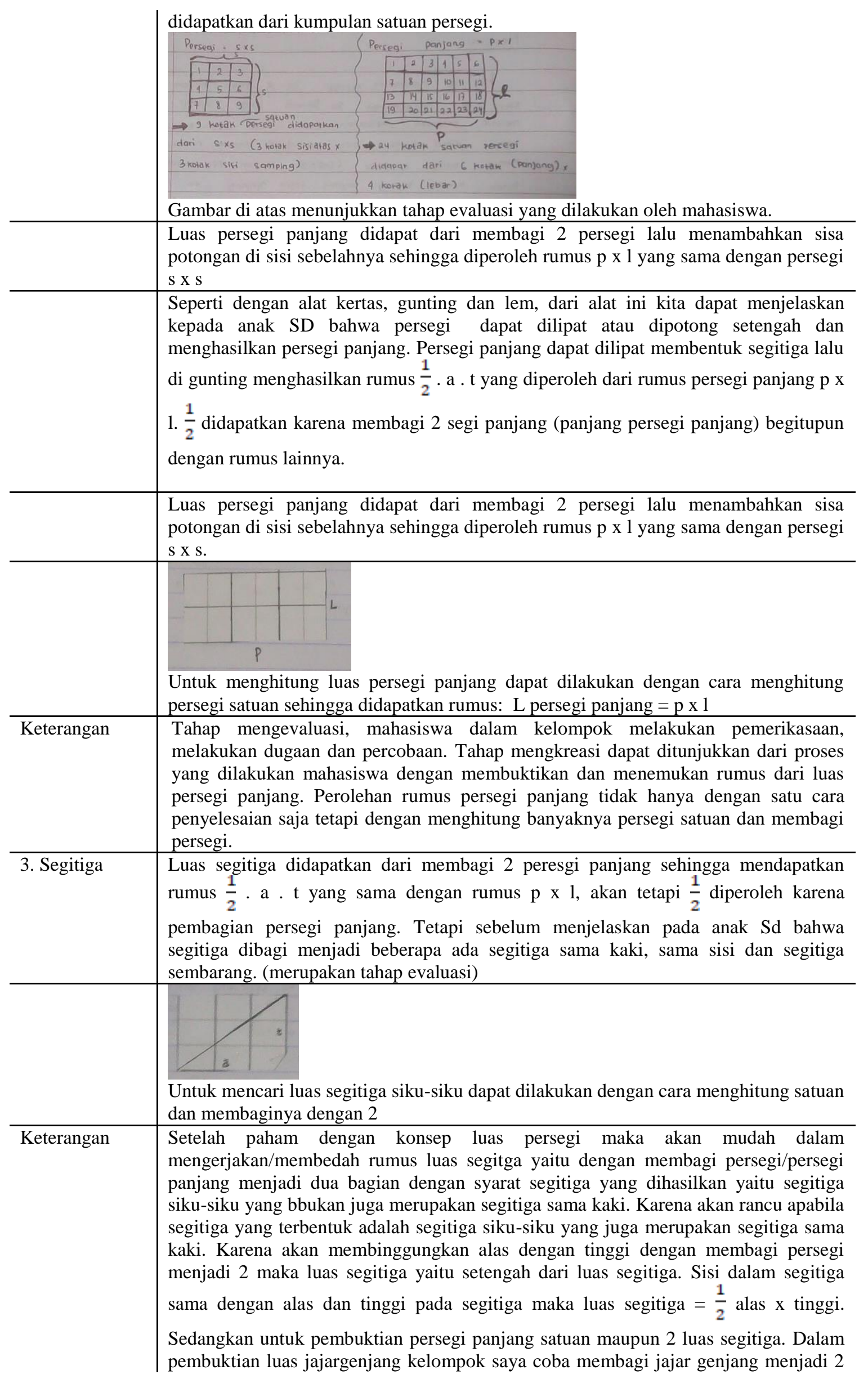


Tinjauan Deskriptif Penerapan Higher Order Thinking dan Problem-Based Learning Pada Mata Kuliah Geometri Berdasarkan Kemampuan Matematika Mahasiswa (Andri Anugrahana)

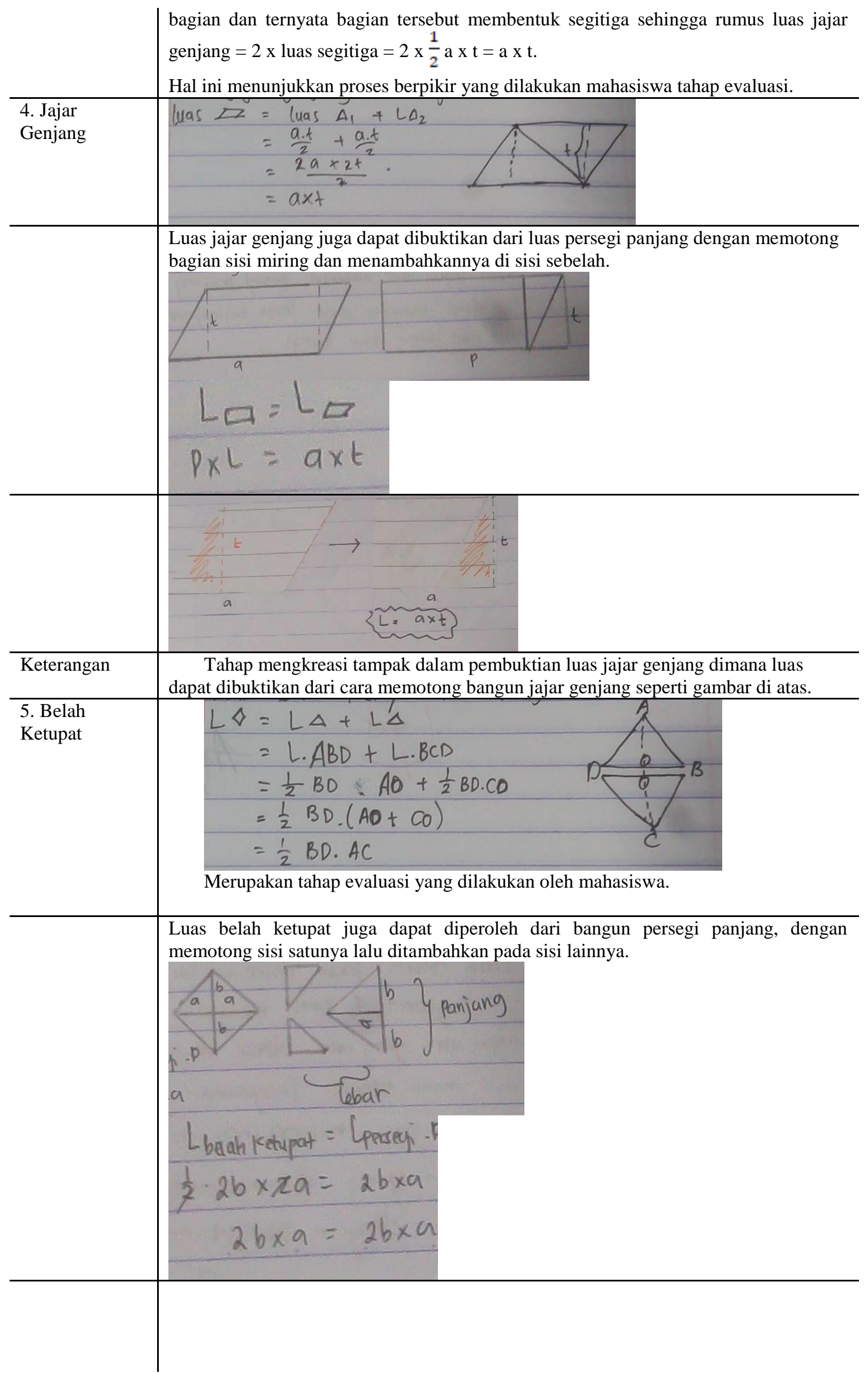




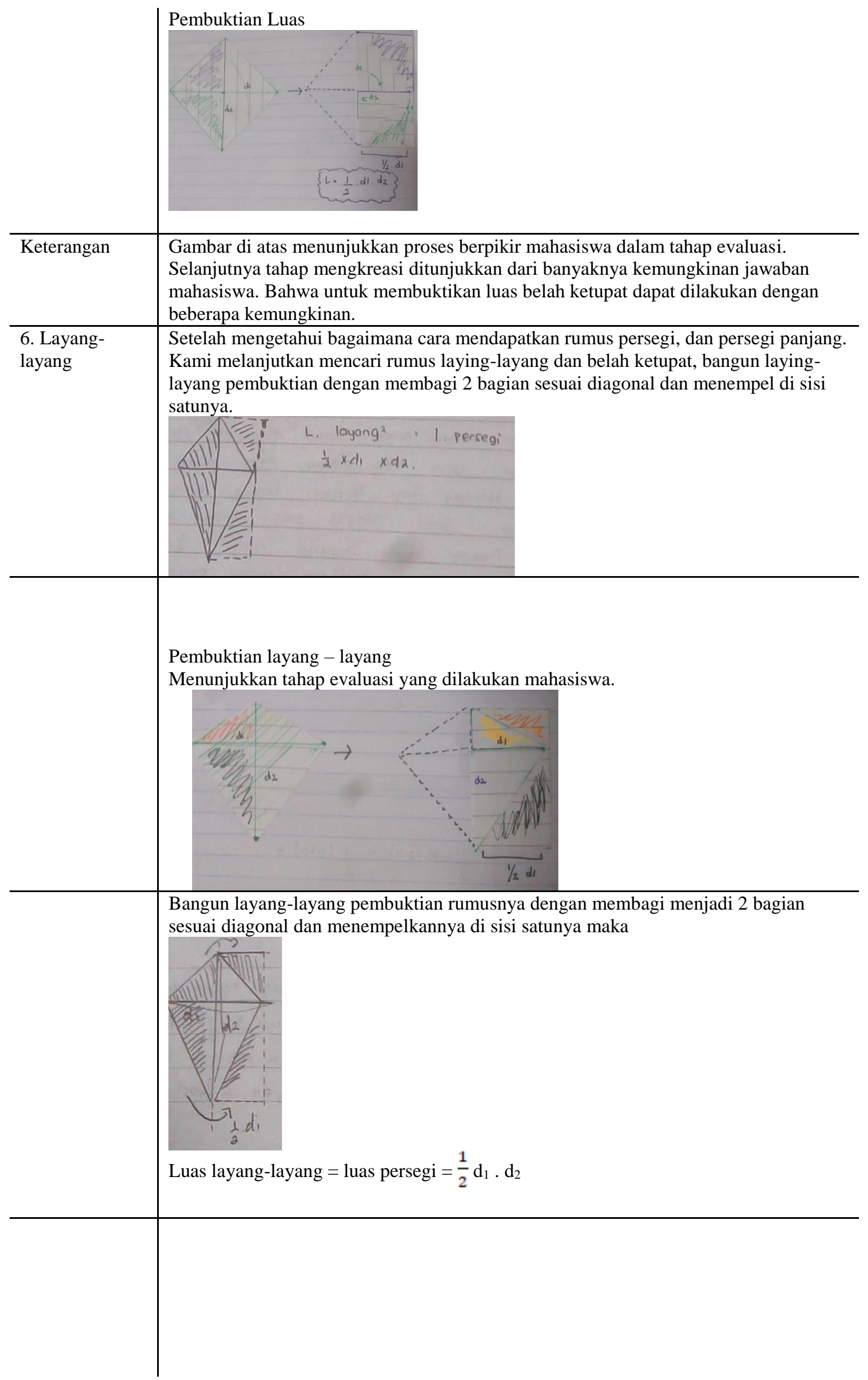


Tinjauan Deskriptif Penerapan Higher Order Thinking dan Problem-Based Learning Pada Mata Kuliah Geometri Berdasarkan Kemampuan Matematika Mahasiswa (Andri Anugrahana)

7. Trapesium $\quad$ Belah ketupat sama halnya dengan belah ketupat. Selanjutnya kami akan membuktikan rumus jajar genjang dalam pembuktian rumus ini kami membagi jajar genjang menjadi 2 bagian

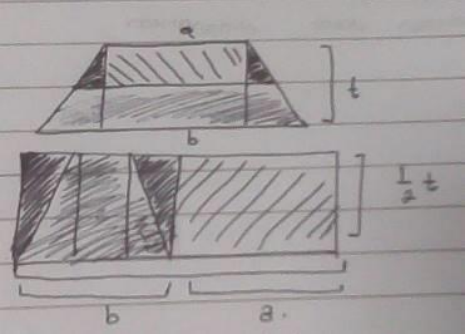

Jadi didapatkan rumus luas trapezium $=$ luas persegi panjang

$$
(\mathrm{a}+\mathrm{b}) \times \frac{1}{2} \cdot \mathrm{t} \quad=\mathrm{p} \times 1
$$

Luas trapesium $=\frac{1}{2}$ (jumlah sisi sejajar) $\mathrm{xt}$

Hal ini menunjukkan tahap evaluasi yang dilakukan oleh mahasiswa.

Luas trapezium didapat dari bangun persegi panjang. Trapezium dibagi menjdai 2 sama tinggi. Lalu sisanya ditambahkan disisi sebelahnya.

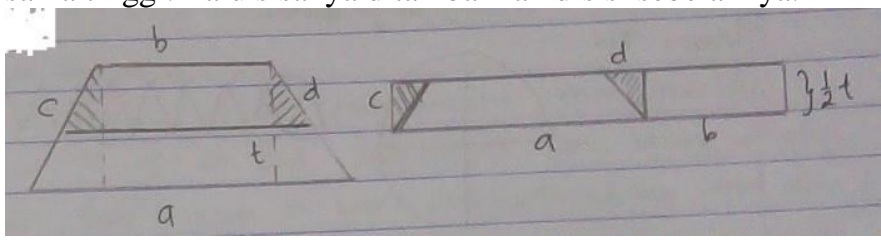

Pembuktian trapesium

walnya saya dan kelompok saya hanya berfokus pada trapezium sama kaki dan mencoba membagi beberapa bagian dan menyisunnya sehingga membentuk bangun persegi panjang

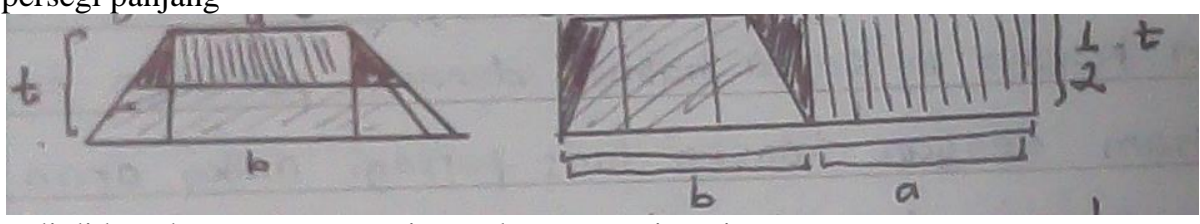

Jadi didapatkan rumus trapezium $=$ luas persegi panjang

$$
(\mathrm{a}+\mathrm{b}) \times \frac{1}{2} \cdot \mathrm{t} \quad \mathrm{p} \times 1
$$

Luas trapezium $=\frac{1}{2}$ (jumlah sisi sejajar) $\mathrm{x} \mathrm{t}$

\begin{tabular}{l|l}
\hline Keterangan & $\begin{array}{l}\text { Tahap mengkreasi nampak dari banyaknya kemungkinan pembuktian trapesium yang } \\
\text { ditemukan oleh mahasiswa. }\end{array}$ \\
\hline & \\
\hline
\end{tabular}


8. lingkaran $\mid$ Setelah mengerjakan tugas yang diberikan, aku baru memahami bagaimana membuktika rumus dari bangun datar. Sekarang aku bisa membuktikan luas dari rumus persegi, segitiga, persegi panjang, jajar genjang, trapezium, laying-layang, belah ketupat dan lingkaran

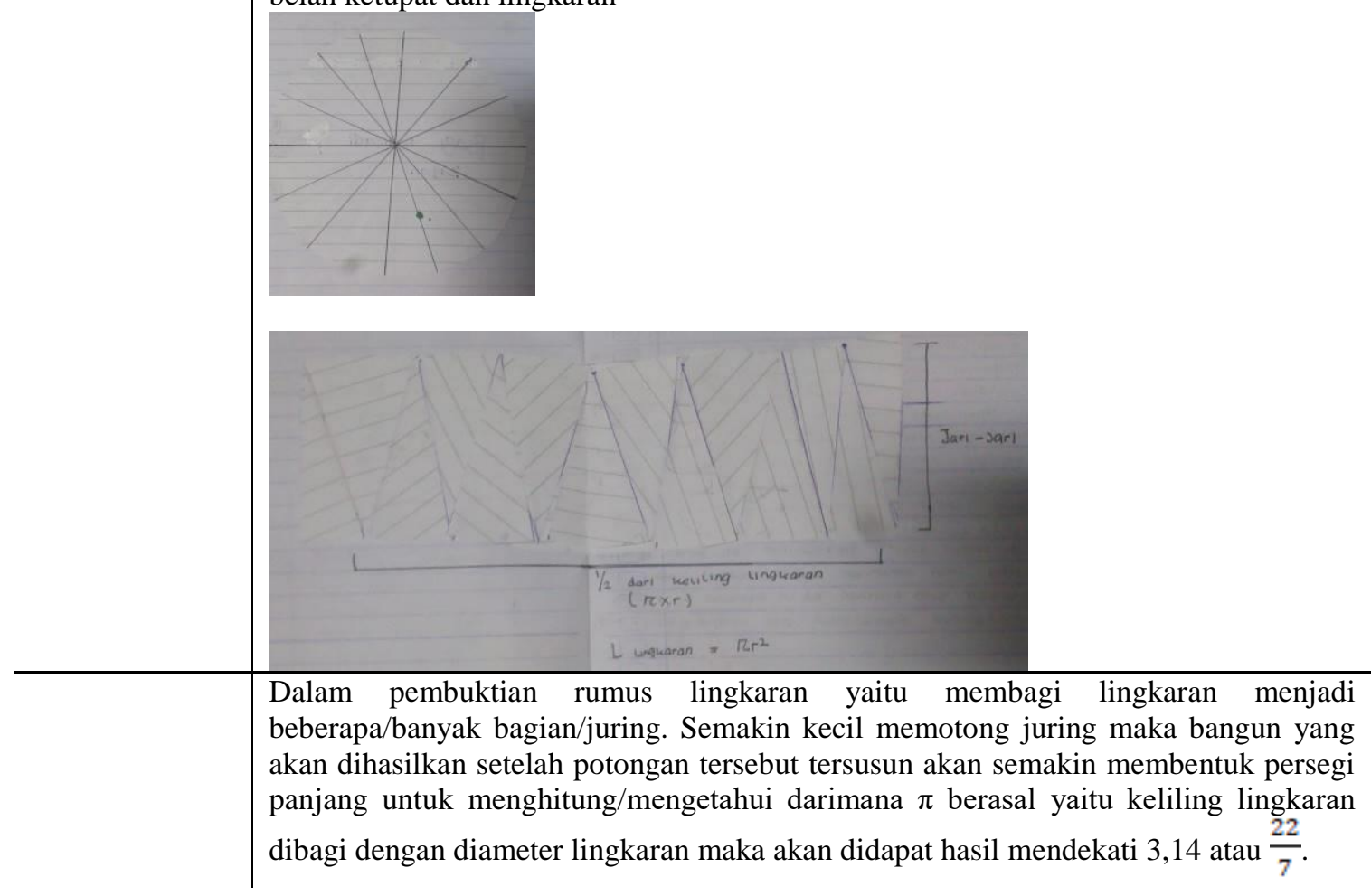

Hasil evaluasi pembelajaran matematika konsep luas bangun datar dengan menggunakan Problem-based Learning dinyatakan oleh reponden sebagai berikut: "Saat dosen menggunakan metode belajar Problem-based Learning. Kami diberi pertanyaan tentang apa itu luas dan keliling, dan bagaimana cara membuktikan luas bangun datar. Sejak dulu saya tidak pernah tau darimana rumus luas bangun datar, dan dari dulu guru saya hanya memberitahu rumusnya saja. Namun dari diskusi kelompok inilah saya dan anggota kelompok 3 saling membantu menemukan cara mendapatkan luas bangun datar. Melalui diskusi kelompok dan presentasi yang dilakukan satu minggu setelahnya, saya awalnya kurang mengerti luas dan cara mendapatkannya, sekarang saya tahu bahwa luas adalah area atau permukaan benda" (transkrip komunikasi pribadi, September 2017).

"Melalui presentasi saya belajar cara menjelaskan sesuatu dan menerima sesuatu yang baru khususnya cara mendapatkan luas. Saya merasa senang karena sekarang saya mengerti dan tahu cara mendapatkannya. Dulunya saya tidak mengerti, menjadi mengerti walaupun prosesnya cukup sulit dan membinggungkan namun saya menikmati setiap proses yang ada. Dari pembelajaran luas bangun datar, saya mendapatkan nilai-nilai kerjasama, teliti, sabar, dan pantang menyerah. Apa yang saya pelajari dan saya gali terus-menerus hingga dasarnya, itulah yang saya ingat. Saya sebagai calon guru SD seharusnya mampu mengajarkan segala sesuatunya dari dasar, khususnya pada matematika, siswa tidak hanya tahu rumusnya namun juga cara mendapatkannya. Dengan demikian, siswa sejak dini akan mengetahui, mengulang-ulang, mengingat, dan terbawa sampai dewasa" (transkrip komunikasi pribadi, September 2017).

"Kami diberi dosen tentang rumus-rumus bangun datar (segitiga, persegi, persegi panjang, belah ketupat, laying-layang, jajar genjang, dan trapesium) tidak hanya sebatas menemukan rumus saja, tetapi kami diminta untuk memecahkan bagaimana rumus tersebut didapatkan. Dalam diri daya, saya masih merasa sangat binggung, bagaimana caranya? Karena sejak SD saya hanya diberi rumus-rumusnya saja tanpa diberitahu oleh 
Tinjauan Deskriptif Penerapan Higher Order Thinking dan Problem-Based Learning Pada Mata Kuliah Geometri Berdasarkan Kemampuan Matematika Mahasiswa (Andri Anugrahana)

guru bagaimana rumus tersebut didapatkan, kami mulai berdiskusi dengan mencaari sumber" (transkrip komunikasi pribadi, September 2017)

"Saat perkuliah geometri dan pengukuran. Saya pertama kali dihadapkan dengan metode pembelajaran berbasis masalah. Disini dihadapkan dengan masalah bagaimana membuktikan luas bangun datar dengan menggunakan media yang ada (kertas, gunting, dan lem) awalnya saya dan kelompok berpikir keras bagaimana dari potongan dan tembelan kertas ini dapat menjeladkan luas bangun datar. Kami mengerjakan mulai dari luas persegi yaitu sisi $x$ sisi. Pembuktian rumus ini dengan menggunakan konsep ini sama halnya dengan perkalian/kuadrat. Setelah paham dengan konsep luas persegi maka akan mudah dalam mengerjakan/membedah rumus luas segitga yaitu dengan membagi persegi/persegi panjang menjadi dua bagian dengan syarat segitiga yang dihasilkan yaitu segitiga siku-siku yang bbukan juga merupakan segitiga sama kaki. Karena akan rancu apabila segitiga yang terbentuk adalah segitiga siku-siku yang juga merupakan segitiga sama kaki. Karena akan membinggungkan alas dengan tinggi dengan membagi persegi menjadi 2 maka luas segitiga yaitu setengah dari luas segitiga" (transkrip komunikasi pribadi, September 2017)

"Dari perkuliahan ini saya diajak untuk memahami dasar-dasar dari rumus tidak hanya menerima rumus tersebut secara mentah-mentah dan saat perkuliahan bagian 2 saya diajak untuk bagaimana menjelaskan suatu konsep agar dapat diterima oleh mahasiswa lain (saat presentasi). Dari perkuliahan ini saya juga diajak untuk mengembangkan pemahaman dasar khusunya bagi siswa sd kelak agar lebih memahami rumus tidak hanya menghapal rumus tersebut dan menanamkan pentingnya suatu proses (berproses)" (transkrip komunikasi pribadi, September 2017).

Beberapa hasil komunikasi pribadi yang diuraikan di atas menggambarkan bahwa mahasiswa dilibatkan dalam proses pembelajaran secara menyeluruh. Mahasiswa mengikuti proses dalam Problem-based Learning. Mulai dari: 1) menyajikan masalah, dimana masalah yang disajikan dalam bentuk open ended dengan berbagai macam penyelesaian.; 2) Selanjutnya mahasiswa dalam kelompok melakukan perencanaan dalam menyelesaikan masalah yang sudah diberikan. Masalah-masalah yang diberikan didiskusikan dalam kelompok. Mahasiswa bersama dalam kelompok menyelesaikan masalah yang sudah disajikan. Tidak hanya menyelesaikan saja tetapi mahasiswa harus dapat menemukan dan melihat kaitan antara konsep yang ada dalam setiap bangun. Dalam pembelajaran geometri mahasiswa mampu mengaitkan konsep yang ada pada bangun ruang dengan benda-benda yang ada dalam kehidupan sehari-hari, yang sejalan dengan pendapat Ety Mukhlesi Yeni (2011:72) yaitu untuk meningkatkan pemahaman konsep matematika siswa dengan menggunakan benda-benda manipulatif.; 3) langkah selanjutnya, mahasiswa dalam kelompok melakukan penyelidikan terhadap masalah yang diberikan. Mahasiswa mencari kemungkinan-kemungkinan yang dapat ditemukan saat melakukan penyelidikan. Seperti pada pembuktian luas dari bangun datar, mahasiswa mampu menemukan beberapa kemungkinan pembuktian. Setelah melakukan penyelidikan, mahasiswa menyajikan hasil diskusi dalam kelompok.; 4) Permasalahan hasil diskusi dengan memresentasikan dan mengevaluasi dan melakukan penyelidikan terhadap pelaksanaan pembelajaran termasuk refleksi. Pada akhir perkuliahan mahasiswa bersama-sama melakukan refleksi. Refleksi berisi saran-saran dari kelompok lain atau mahasiswa lain kepada kelompok yang presentasi.

Bentuk permasalahan yang diberikan adalah pembuktian dari luas bangun-bangun datar, dengan berbagai kemungkinan yang ditemukan oleh mahasiswa. Tujuan dari pembuktian bangun datar adalah mahasiswa dapat melihat kaitan antar bangun geometri, dan mampu memahami konsep dan prosedur dalam pembelajaran matematika materi geometri. Poin aktivitas mengaitkan materi geometri, konsep dan prosedurnya berbanding lurus dengan penelitian yang dilakukan Wahyu dan Indri (2017) yang menekankan pada pemahaman 
konsep dan prosedural matematika dalam perkuliahan. Mahasiswa diminta mempresentasikan hasil kerja kelompok untuk menjelaskan bagian persegi dan persegi panjang, dan kelompok yang lainpun diminta untuk mempresetasikannya juga. Banyak cara yang mereka dapatkan, dan banyak pula cara mempresentasikannya. "Saya bisa banyak belajar dari matakuliah pertama ini. Mulai dari bagaimana caranya alat dan bahan yang sederhana bisa untuk metode belajar untuk anak didik nantinya. Hingga cara memaparkan dan menjelaskan apa yang kami dapatkan."

Mahasiswa mencari, menemukan dan menjelaskan asal dan pembuktiannya, sehingga ketika ada anak SD yang bertanya saya sebagai guru dapat menjawab sebagaimana mestinya seorang guru menjelaskan. Anak-anak pun tidak terpaut pada rumus-rumus yang terkadang membuat mereka membenci matematika (khusunya bangun datar). Langkah selanjutnya mahasiswa mempresentasikan hasil dari yang dikerjakan minggu lalu. Dari hasil kegiatan ini dapat disimpulkan hubungan dari bangun datar adalah

a. Luas persegi dapat dicari dengan membagi persegi menjadi 16 bagian, sehingga didapatkan hasil sisi $\mathrm{x}$ sisi

b. Luas persegi panjang didapat dari membagi 2 persegi lalu menambahkan sisa potongan di sisi sebelahnya sehingga diperoleh rumus $\mathrm{p}$ x 1 yang sama dengan persegi S X S

c. Luas segitiga didapatkan dari membagi 2 peresgi panjang sehingga mendapatkan rumus $\frac{1}{2}$. a . t yang sama dengan rumus $\mathrm{p}$ x 1 , akan tetapi ${ }^{\frac{1}{2}}$ diperoleh karena pembagian persegi panjang. Tetapi sebelum menjelaskan pada anak Sd bahwa segitiga dibagi menjadi beberapa ada segitiga sama kaki, sama sisi dan segitiga sembarang.

d. Luas trapezium didapat dari bangun persegi panjang. Trapezium dibagi menjdai 2 sama tinggi. Lalu sisanya ditambahkan disisi sebelahnya.

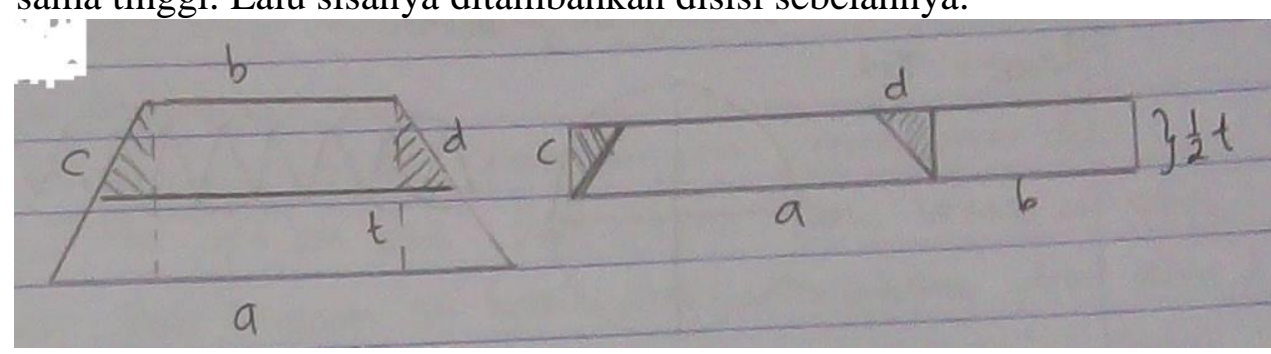

e. Luas jajar genjang juga dapat dibuktikan dari luas persegi panjang dengan memotong bagian sisi miring dan menambahkannya di sisi sebelah.

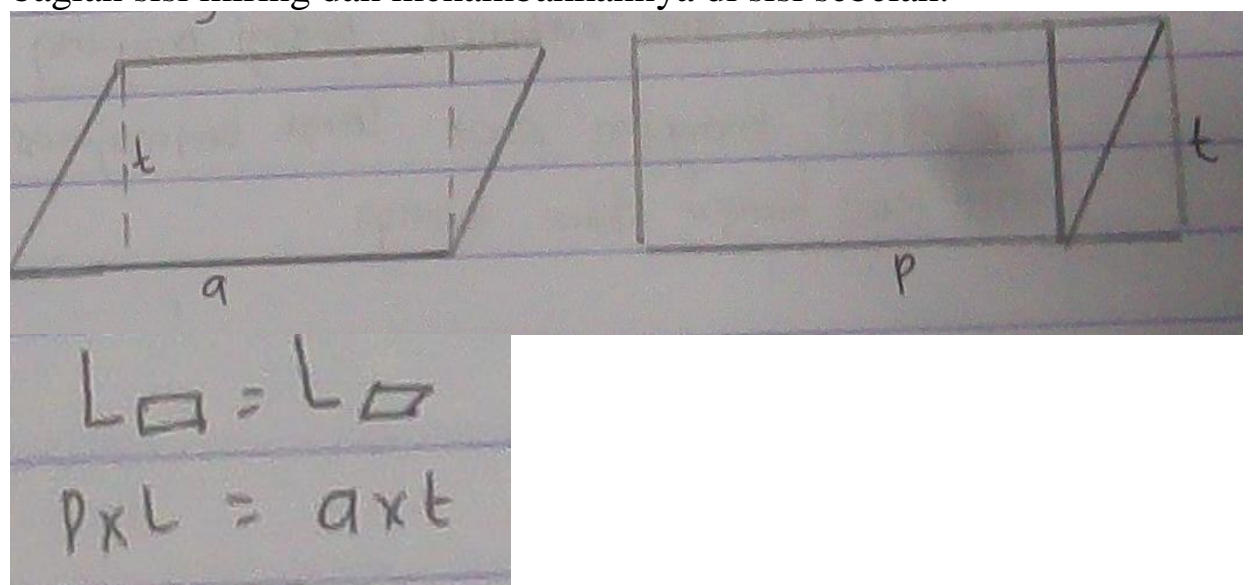

f. Luas belah ketupat juga dapat diperoleh dari bangun persegi panjang, dengan memotong sisi satunya lalu ditambahkan pada sisi lainnya. 


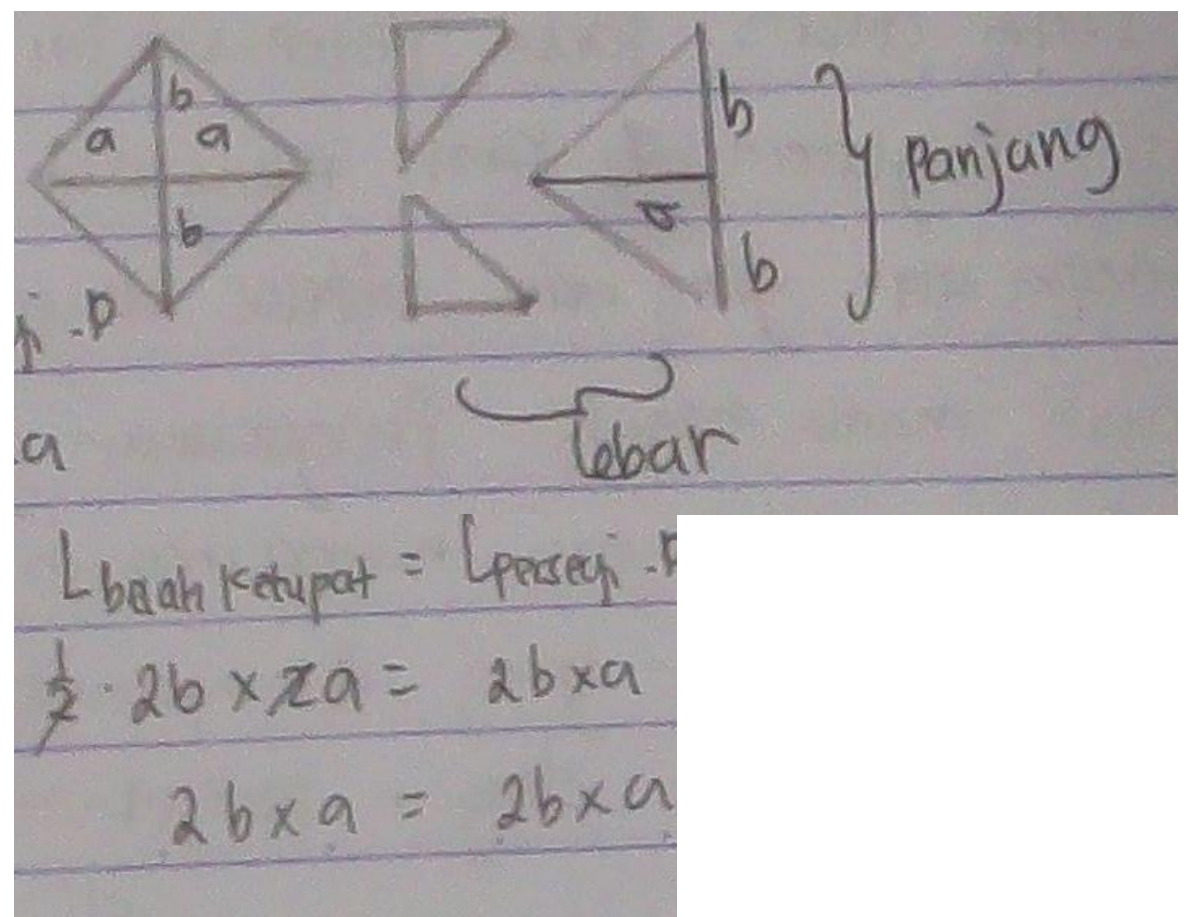

g. Lingkaran dapat diperoleh dengan membagi lingkaran membentik juring-juring lalu meletakkan di sisi lainnya, sehingga membentuk persegi panjang

$\Pi=>$ konstanta keliling dengan diameter

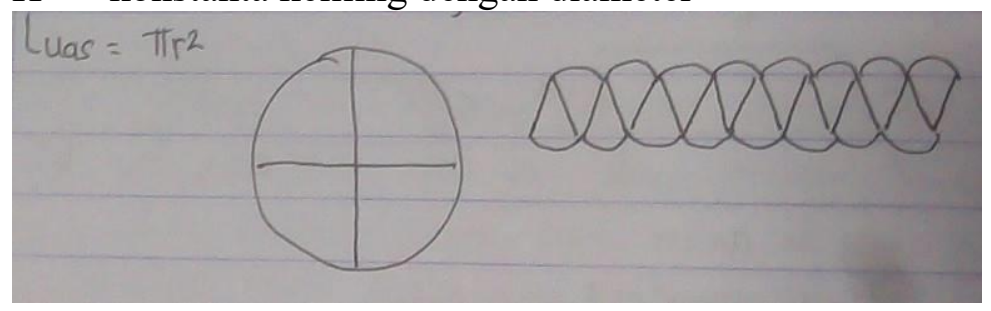

Hal ini menunjukkan mahasiswa sudah melakukan proses berpikir tingkat tinggi yaitu menganalisis, mengevaluasi dan mengkreasi. Dalam proses menganalisa mahasiswa membuktikan rumus dari luas bidang datar. Tahap mengevaluasi, mahasiswa dalam kelompok melakukan pemerikasaan dari pembuktian yang dilakukan, melakukan dugaan dengan mencari berbagai kemungkinan jawaban. Selanjutnya tahap mengkreasi, yaitu mahasiswa mampu menciptakan dan menemukan berbagai kemungkinan jawaban dalam pembuktian bangun datar.

\section{SIMPULAN DAN SARAN}

Penggunaan model Prablem Based Learning, memberikan kesempatan kepada mahasiswa untuk terlibat dalam pembelajaran, dan berani mengungkapkan ide-ide dalam pembelajaran. Bahkan lebih kreatif dalam mengungkapkan ide-ide dalam pembelajaran.

Hasil dari penelitian ini adalah mahasiswa mengalami proses ketrampilan tingkat tinggi yaitu menganalisis, mengevaluasi dan mengkreasi. Dalam proses menganalisa mahasiswa membuktikan rumus dari luas bidang datar. Tahap mengevaluasi, mahasiswa dalam kelompok melakukan pemerikasaan, melakukan dugaan, percobaan dan menguji dugaan-dugaan dari yang sudah dilakukan. Selanjutnya tahap mengkreasi, saat mahasiswa mampu menciptakan dan menemukan berbagaai kemungkinan jawaban dalam pembuktian bangun datar. Sejalan dengan penelitian Sri Sukaptiyah (2015) bahwa model pembelajaran Problem Based Learning dengan mengefektifkan alat peraga mampu meningkatkan hasil belajar siswa. 


\section{DAFTAR PUSTAKA}

Ade Gunawan. (2012). Penerapan Model Pembelajaran Berbasis Masalah untuk Meningkatkan Keterampilan Berpikir Kritis Siswa SMA Negeri 2 Metro. Pendidikan Biologi FKIP Universitas Muhammadiyah Metro. Email:aa_gun8987@yahoo.com

Aisyah, Nyimas, Zulkardi dan Lewy. 2009. Pengembangan Soal Untuk Mengukur Kemampuan Berpikir Tingkat Tinggi Pokok Bahasan Barisan dan Deret Bilangan di Kelas IX Akselerasi SMP Xaverius Palembang. http://eprints.unsri.ac.id/820/1/2_Lewy_14-28.pdf diakses tanggal 21 April 2018

Arends, R. I. 2012. Learning to Teach. New York: Mc Graw-Hill.

Depdiknas. (2003). Kumpulan Pedoman Kurikulum 2004. Jakarta: Depdiknas

Fadjar, Shadiq. Laporan Hasil Seminar dan Lokakarya Pembelajaran Matematika 15-16 Maret 2007 di P4TK (PPPG) Matematika Yogyakarta Forehand,M .2005. Bloom Taxonomy: Original and Revised tersedia di https://www.scribd.com/doc/78216950/laporan-hasil-seminar-dan-lokakaryapembelajaran-matematika-15-16-maret-2007-di-p4tk-pppg-matematika diakses tanggal 23 April 2018

Krathwohl, R. (2012). A Revision of Bloom's Taxonomy: An Overview. http://ocw.metu.edu.tr/pluginfile.php/9009/mod_resource/content/1/s15430421tip410 4_2.pdf diakses tanggal 23 Aprl 2018 .

Nugrahani, R. (2007). Media Pembelajaran Berbasis Visual Berbentuk Permainan Ular Tangga untuk Meningkatkan Kualitas Belajar Mengajar di Sekolah Dasar. Lembaran Ilmu Kependidikan, 36(1).

Ayuningtyas, N., Rahaju, Endah B.. Jurusan Matematika, Universitas Negeri Surabaya Surabaya 60231. http://ejournal.unesa.ac.id/jurnal/mathedunesa/abstrak/2702/prosespenyelesaian-soal-higher-order-thinking-materi-aljabar-siswa-smp-ditinjauberdasarkan-kemampuan-matematika-siswa. diakses tanggal 15 Januari 2018.

Sukaptiyah, S. (2015). Peningkatan Hasil Belajar PKn Melalui Model Problem Based Learning Pada Siswa Kelas VI SD Negeri 1 Mongkrong, Wonosegoro. Scholaria: Jurnal Pendidikan dan Kebudayaan, 5(1), 114-121.

Susanto, Heri Ratnawati, 2016. Perangkat Pembelajaran Matematika Bercirikan PBL untuk Mengembangkan HOTS Siswa SMA. Jurnal Riset Pendidikan Matematika. Print ISSN: 2356-2684, Online ISSN: 2477-1503.

Soviawati, E. (2011). Pendekatan matematika realistik (pmr) untuk meningkatkan kemampuan berpikir siswa di tingkat sekolah dasar. Jurnal Edisi Khusus, 2(2), 79-85.

Murray, E., C. (2011). Implementing higherorder thinking in middle school mathematics classrooms. Dissertation Submitted to the Graduate Faculty of The University of Georgia,Georgia. Tersedia di file:///E:/ARTIKEL_PGSD/HOTS/10631-28233-2PB.pdf Diakses tanggal 23 April 2018.

Rakhmawati, Y; Chamdani M; Chrysti S K. (2013). Penerapan Model PBL dalam Peningkatan Berpikir Kritis IPA Siswa Kelas V SD. Kalam Cendekia PGSD Kebumen, 3(2).

Retnawati, H., Susanto, E. (2016) Perangkat pembelajaran Matematika Bercirikan PBL untuk Mengembangkan HOTS siswa SMA. Jurnal Riset Pendidikan Matematika 3 (2), 189 197. 
Tinjauan Deskriptif Penerapan Higher Order Thinking dan Problem-Based Learning Pada Mata Kuliah Geometri Berdasarkan Kemampuan Matematika Mahasiswa (Andri Anugrahana)

Pramudita, W., \& Anugraheni, I. (2017). Studi Penguasaan Matematika Dan Bahasa Inggris Mahasiswa Program Studi Pendidikan Guru Sekolah Dasar (PGSD). Scholaria: Jurnal Pendidikan Dan Kebudayaan, 7(1), 70-82.

Yeni, E. M. (2011). Pemanfaatan Benda-Benda Manipulatif untuk Meningkatkan Pemahaman Konsep Geometri dan Kemampuan Tilikan Ruang Siswa Kelas V Sekolah Dasar. Jurnal Edisi Khusus, 1, 63-75. 